\title{
Heuristic introduction to weakly Picard operator theory
}

\author{
IOAN A. RUS
}

\section{ABSTRACT.}

In this paper we study the impact of weakly Picard operator theory, [see I. A. Rus, Picard operators and applications, Sc. Math. Japonicae, 58 (2003), No. 1, 191-219] on the following problem: what can we do in order to find conditions under which a given operator is a weakly Picard operator?

\section{REFERENCES}

[1] Abel, U. and Ivan, M., Over-interates of Bernsteinś operators: A short and elementary proof, Amer. Math. Monhly, 116 (2009), No. 6, 535-538

[2] Adell, J. A., Germán Badia, F. and Jesús de la Cal,. On the iterates of some Bernstein-type operators, J. Math. Anal. Appl., 209 (1997), 529-541

[3] Agratini, O. and Rus, I. A., Iterates of a class of discrete linear operators via contraction principle, Comment. Math. Univ. Carolin, 44 (2003), No. 3 , 555-563

[4] Agratini, O. and Rus, I. A., Iterates of some bivariate approximation process via weakly Picard operators, Nonlinear Anal. Forum, 8 (2003), No. 2, 159-168

[5] Agratini, O., Aproximare prin operatori liniari, Presa Universitară Clujană, Cluj-Napoca, 2000

[6] Altomare, F. and Campiti, M., Korovkin-type approximation theory and its applications, de Gruyter, Berlin, 1994

[7] András, S. and Rus, I. A., Iterates of Cesàro operators, via fixed point principle, Fixed Point Theory, 11 (2010), No. 2, 171-178

[8] Bauer, H., Approximation and abstract boundaries, Amer. Math. Monthly, 85 (1978), No. 8, 632-647

[9] Berinde, V., Iterative Approximation of Fixed Points, Springer, 2007

[10] Berinde, V., Păcurar, M. and Rus, I. A., From a Dieudonné theorem concerning the Cauchy problem to an open problem in the theory of weakly Picard operators, Carpathian J. Math., 30 (2014), No. 3, 283-292

[11] Bohl, E., Linear operator equations on a partially ordered vector space, Aequat. Math., 4 (1970), 89-98

[12] Boyd, D. W., The spectral radius of averaging operators, Pacific J. Math, 24 (1968) 19-28

[13] Cătinaş, T. and Otrocol, D., Iterates of Bernstein type operators on a square with one curved side via contraction principle, Fixed Point Theory, 13 (2012), No. 1, 97-106

[14] Cătinaş, T. and Otrocol, D., Iterates of multivariate Cheney-Sharma operators, J. Comput. Anal. Appl., 15 (2013), 1240-1246

[15] Chiş-Novac, A., Precup, R. and Rus, I. A., Data dependence of fixed points for non-self generalized contractions, Fixed Point Theory, 10 (2009), No. $1,73-87$

[16] Cristescu, R., Spaţii liniare ordonate, Editura Academiei R. P. R., Bucureşti 1959

[17] Cristescu, R, Ordered vector spaces and linear operators, Abacus Press, 1976

[18] Engelking, R., General Topology, PWN, 1977

[19] Gal, S. G., Voronovskaja's theorem and iterations for complex Bernstein polynomials in compact disks, Mediterr. J. Math, 5 (2008), 253-272

[20] Gavrea, I. and Ivan, M., On the iterates of positive linear operators, J. Approx. Theory, 163 (2011), 1076-1079

[21] Gavrea, I. and Ivan, M., The iterates of positive linear operators preserving constants, Appl. Math. Lett., 24 (2011), $2068-2071$

[22] Gonska, H., Kacsó, D. and Piţul, P., The degree of convergence of over-iterated positive linear operators, J. Appl. Funct. Anal, 1 (2006), 403-423

[23] Gonska, H. and Piţul, P., Remarks on an article of J. P. King, Comment. Math. Univ. Carolin., 46 (2005), No. 4, 645-652

[24] Gonska, H., Piţul, P. and Raşa, I., Over-iterates of Bernstein-Stancu operators, CALCOLO, 44 (2007), 117-125

[25] Gonska, H. and Raşa, I. The limiting semigroup of the Bernstein iterates: degree of convergence, Acta Math. Hungar, 111 (2006), No. 1-2, 119-130

[26] Heikkilä, S. and Roach, G. F., On equivalent norms and the contraction mapping principle, Nonlinear Anal, 8 (1984), No. 10, 1241-1252

[27] Holmess, R. B., A formula for the spectral radius of an operator, Amer, Math. Monthly, 75 (1968), 163-166

[28] Jachymski, J., Convergence of iterates of linear operators and the Kelisky-Rivlin type theorems, Studia Math., 195 (2009), No. 2, $99-112$

[29] Jamenson, G., Ordered Linear Spaces, Springer, 1970

[30] Kantorović, L. V. and Akilov, G. P., Analiză funcţională, Editura Ştiinţifică şi Enciclopedică, Bucureşti, 1986

[31] Kantorović, L. V., Vulikh, B. C. and Pinsker, A. G., Functional Analysis in Partially Ordered Spaces, (Russian), Moscow-Leningrad, 1950

[32] Karlin, S. and Ziegler, Z., Iteration of positive approximation operators, J. Approximation Theory, 3 (1970), 310-339

[33] King, J. P., Positive linear operators which preserve $x^{2}$, Acta Math. Hungar., 99 (2003), 203-208

[34] Kuratowski, K., Topology I, Acad. Press, 1966

[35] La Salle, J. P., The stability of dynamical sistems, SIAM, 1976

[36] Mahmudov, N. I., Asymptotic properties of powers of linear positive operators which preserve e 2 , Comput. Math. Appl., 82 (2011), $4568-4575$

[37] Ortega, J. M. and Rheinboldt, W. C., Iterative solution of nonlinear equations in several variables, Acad. Press, 1970

[38] Păcurar, M., Fixed point theory for cyclic Berinde operators,Fixed Point Theory, 12 (2011), No. 2, 419-428

[39] Petruşel, A., Rus, I. A. and Şerban, M. A., The role of equivalent metrics in fixed point theory, Topol. Methods Nonlinear Anal., 41 (2013), No. 1, 85-112

[40] Raşa, I., Asymptotic behaviour of iterates of positive linear operators, Jaen J. Approx., 1 (2009), No. 2, 195-204

[41] Raşa, I., Positive linear operator preserving linear functions,Ann. T. Popoviciu Seminar of Funct. Eq. Approx. Conv., 7 (2009), 105-109

[42] Rus, I. A., Picard operators and applications, Sc Math. Japonicae, 58 (2003), No. 1,191-219

[43] Rus, I. A., Fixed Point Structure Theory, Cluj University Press, Cluj-Napoca, 2006

[44] Rus, I. A., Iterates of Bernstein operators, via contraction principle, J. Math. Anal. Appl, 292 (2004), 259-261

[45] Rus, I. A., Fixed point and interpolation point set of a positive linear operator on $C(\bar{D})$, Studia Univ. Babeş-Bolyai, Math., 55 (2010), No, 4, $243-248$

Received: 09.10.2014; In revised form: 21.11.2014; Accepted: 25.11.2014

2010 Mathematics Subject Classification. 47H10, 06B30, 54A20, 54F05, 47A30, 47B60, 47B65.

Key words and phrases. L-space, $L$-space linear lattice, $L^{*}$-space, order unit,order unit with respect to a subset, metric space, normed space, iterates of an operator, weakly Picard operator, fixed point partition of a set with respect to an operator, positive linear operator. 
[46] Rus, I. A., Interates of Stancu operators (via fixed ponit principle) revisited, Fixed Point Theory, 11 (2010), No. 2, 369-374

[47] Rus, I. A., Petruşel, A. and Petruşel, G., Fixed Point Theory, Cluj University Press, 2008

[48] Rus, I. A., Five open problems in the fixed point theory in terms of fixed point structures (I): singled valued operators, 39-60 in Proceed. of the $10^{\text {th }}$ IC-FPTA, Cluj-Napoca, 2013

[49] Rus, I. A., An abstract point of view on iterative approximation of fixed points: impact on the theory of fixed point equations, Fixed Point Theory, 13 (2012), No. 1, 179-192

[50] Rus, I. A. Some nonlinear functional and integral equations, via weakly Picard operator theory: a survey, Carpathian J. Math., 26 (2010), No. 2, 230-258

[51] Schaefer, H. H., Banach lattice and positive operators, Springer, 1974

[52] Trotter, H. F., Approximation of semi-groups of operators, Pacific J. Math., 8 (1958), 887-919

[53] Vulikh, B. Z., Introduction to the theory of partially ordered spaces, Wolters-Noordhoff, 1967

BABEŞ-BOLYAi UNiVERSity OF CluJ-NAPOCA

DEPARTMENT OF MATHEMATICS

KOGĂLNiCEANU NR. 1, 400084, ClUJ-NAPOCA, ROMANIA

E-mail address: iarus@math.ubbcluj.ro 